Rand, Jane ORCID:

https://orcid.org/0000-0002-2314-6761 (2013) Action learning and constructivist grounded theory: powerfully overlapping fields of practice. Action Learning: Research and Practice, 10 (3). pp. 230243.

Downloaded from: http://ray.yorksj.ac.uk/id/eprint/25/

The version presented here may differ from the published version or version of record. If you intend to cite from the work you are advised to consult the publisher's version: http://dx.doi.org/10.1080/14767333.2013.821968

Research at York St John (RaY) is an institutional repository. It supports the principles of open access by making the research outputs of the University available in digital form. Copyright of the items stored in RaY reside with the authors and/or other copyright owners. Users may access full text items free of charge, and may download a copy for private study or non-commercial research. For further reuse terms, see licence terms governing individual outputs. Institutional Repository Policy Statement

\title{
RaY
}

Research at the University of York St John

For more information please contact RaY at ray@yorksj.ac.uk 
This is an electronic version of an article published in Rand, J. (2013) Action learning and constructivist grounded theory: powerfully overlapping fields of practice. Action Learning Research and Practice, 10(3), 230-243. DOI: 10.1080/14767333.2013.821968 ACTION LEARNING RESEARCH AND PRACTICE is available online at: http://www.tandfonline.com/doi/abs/10.1080/14767333.2013.821968?journalCode =calr20\#.VQhAqdKsXgc

\section{Action Learning and Constructivist Grounded Theory: powerfully overlapping fields of practice.}

This paper considers the shared characteristics between action learning and the research methodology constructivist grounded theory. Mirroring Edmonstone's article (2011), which explored the relationship/s between action learning and organisation development, a case is made that action learning and constructivist grounded theory are powerfully overlapping fields of practice. An account of practice is included to provide a contextual explanation of the 'overlap', and a new methodological praxeology is proposed to the field of practice-/practitionerfocussed research.

Keywords: action learning; constructivist grounded theory; practice-focussed research

\section{Introduction - Action learning and constructivist grounded theory: overlapping fields of practice?}

Grounded theory is an inductive, systematic, research method which relates a theory to the focus of [a] study; it emphasises social processes and non-mathematical interpretation. It was developed as an alternative to a dominant positivist research arena in the 1960s by Barney Glaser and Anselm Strauss and is based on the procedural principles of gathering data, coding, categorising, comparing, theoretically sampling, developing [a] core category/ies and generating theory. 
Grounded theory (the method) is subject to reinvention (Morse 2009b), rooted in professional practice (Thomas and James 2006; Walker and Myrick 2006), and suited to 'capturing the complexities of the context in which the action unfolds' (Locke 2001, 95 emphasis added). Grounded theories (the products) serve as both 'a way to learn about the worlds we study and a method for developing theories to understand them' (Charmaz 2006, 10). They are geared towards constructing (rather than discovering) descriptive and explanatory theories (Charmaz 2006, 2009; Shannak and Aldhmour 2009), and 'are likely to offer insight, enhance understanding and provide a meaningful guide to action' (Strauss and Corbin 1998, 12).

Constructivist grounded theory is a second generation innovation from the original method (Stern 2009). It 'sees knowledge as socially produced...takes a reflexive stance ... [and] assumes that we produce knowledge by grappling with empirical problems' (Charmaz 2009, 129-130).

Action strategies such as action research and action learning are built upon collaborative and reflexive development of understanding (Pedler, Burgoyne and Brook 2005, 52); they link the targets of inquiry to their context (Plauborg 2009). Action strategies are process-oriented, systematic, reflective, and geared towards improvement. In common with grounded theory, they are underpinned by the principle that humans actively construct their own meaning (new knowledge).

There is much discussion around the absence of a precise definition of what action learning is (Simpson and Bourner 2007; Pedler, Burgoyne and Brook 2005; Rigg and Trehan 2004). The irreducible elements of action learning are, however, widely agreed:

- (Personal) action as the basis of learning. 
- A focus on real, contextualised, problems (characterised by complexity and uncertainty).

- The use of questioning insight, geared towards goal-directed and reflective thinking, as a vehicle for learning.

- Emergent learning outcomes.

- Collaborative (social) exploration ('comrades in adversity'), which is nonhierarchical and virtuous in nature.

- A (self) developmental, rather than operational, focus.

(Fox 2009; Simpson and Bourner 2007; Pedler, Burgoyne and Brook 2005; Rigg and Trehan 2004)

Simpson and Bourner (2007: 175 citing Pedler's earlier work from 1997) forgo a definition and promote the philosophy rather than the practice of action learning, arguing that those who subscribe to it are obliged to acknowledge 'acceptable practice and refrain from colluding with unacceptable practice'. They argue, instead, for action learning researchers to express explicitly their (personal) understandings. For them, action learning is:

learning from tackling significant problems in the real world through cycles of new action and reflection in the good company of those who can help to explore emergent issues with fresh questions. (Simpson and Bourner 2007, 184)

Marsick and O’Neil (1999 cited in McGill and Beaty 2001) identify a typology of three 'schools' of action learning: the scientific school (based on Revans' original work), the experiential school (based on experiential learning theory), and the critical reflection 
school. The critical reflection school builds on experiential learning theory and draws on Mezirow's (1981) work on transforming perspective/s ${ }^{1}$.

As a novice action learner researcher, the irreducible elements (above), the fundamental 'principles of praxis, process, proactivity and reflexivity' (Rigg and Trehan 2004, 152), and [for me] the concept of critical colleagueship ${ }^{2}$ (Lord 1994) 'define' action learning. And so, my personal understanding of action learning is:

development-oriented learning through collaborative engagement with real problems, based on questioning insight and critically reflective thinking. (Rand, 2011: 42)

Action strategies and a grounded theory methodology lend themselves towards the study of the particular. A relationship between action learning and second-generation grounded theory, however, has yet to be established in the literature. This paper argues that synthesising critical reflection action learning and constructivist grounded theory results in a robust research partnership, and presents it to the field of practice/practitioner-focused research as a new methodological praxis.

\section{Constructivist grounded theory and critical reflection action learning as research partners}

Constructivist grounded theory (CGT) recognises idiosyncrasy (Bryant and Charmaz 2010), and a strength of action learning (AL) is its ability to turn personal understanding into shared knowledge (Bourner and Simpson 2005, 145 original

\footnotetext{
${ }^{1}$ Mezirow argues that assumptions constrain agents' perceptions, and a critical awareness of these can result in transformation of 'meaning schemes' and more inclusive perspectives

${ }^{2}$ collaborative discussion geared towards 'gaining a deeper understanding and development of practice' (Plauborg 2009, 31)
} 
emphasis). Revans (1983 cited in McGill and Beaty 2001) argues that action learning acts as a bridge between the world of action and the world of learning. I argue that a grounded theory methodology enables the nature of that bridge to be explored. CGT leads to situated knowledge (Morse 2009a, 136 citing Haraway 1991) and enables researchers to convey what is 'going on' (Morse 2009b, 14) 'relative to the social circumstances impinging on it' (Charmaz 2009, 134). CGT surfaces context, and context is the unique selling point of action approaches. The combination, therefore, of CGT and AL is particularly useful within professional research.

My argument for a new methodological praxis centres on the principle that CGT and critical reflection action learning share the majority of significant characteristics, whilst the developmental focus towards which each is geared is different (Table 1). Critical reflection action learning is geared towards self-development; constructivist grounded theory is geared towards the development of meaning. The combination of the two promises a powerful synergy to the field of practice-/practitioner-focused research. 
Table 1. Shared characteristics: action learning and grounded theory.

\begin{tabular}{|c|c|c|}
\hline $\begin{array}{l}\text { Discrete } \\
\text { characteristics of } \\
\text { (critical } \\
\text { reflection) action } \\
\text { learning }\end{array}$ & SHARED CHARACTERISTICS & $\begin{array}{l}\text { Discrete } \\
\text { characteristics of } \\
\text { (constructivist) } \\
\text { grounded theory } \\
\text { methodology }\end{array}$ \\
\hline $\begin{array}{l}\text { (self-) } \\
\text { Development- } \\
\text { oriented. }\end{array}$ & $\begin{array}{l}\text { - } \text { Making (analytical) sense of } \\
\text { - } \quad \text { Focus on empirical realities and } \\
\text { social processes. } \\
\text { - } \quad \text { Rich description. } \\
\text { - } \text { Insight and elaboration, resultant } \\
\text { from questioning and reflection. } \\
\text { - Emphasis on action and process. } \\
\text { - } \quad \text { Surfaces subjectivity. } \\
\text { - Families of methods. } \\
\text { - Emergent [inductive] outcomes. } \\
\text { - } \quad \text { Turns personal understanding into } \\
\text { - } \text { shared knowledge. } \\
\text { interrelationship between theory \& } \\
\text { - } \text { practice. } \\
\text { Pragmatically oriented. }\end{array}$ & $\begin{array}{l}\text { Focus on the } \\
\text { development of } \\
\text { meaning. }\end{array}$ \\
\hline
\end{tabular}

The explicit link between action approaches and constructivist grounded theory methodology is agency. These waters are not entirely uncharted. In their paper on grounded action research Baskerville and Pries-Heje $(1999,2)$ identified that action research could be 'powerfully improved' when merged with some of the techniques of grounded theory; they determined, however, that this powerful improvement was not reciprocal. Similarly, links have been identified (and challenged) between agency in 
grounded theory and symbolic interaction ${ }^{3}$ (Bryant and Charmaz 2010). AL is differentiated from symbolic interaction by the disciplinary focus on learning. The focus on learning, through critically reflective thinking, powerfully improves the techniques of grounded theory.

A praxeological approach - uniting doing and knowing (Coghlan and Pedler 2006, 132) fosters a sufficiently rich and contextual research arena to enable practitioner-researchers to explore tacit and subjective understanding, agents' perspectives, and to delve in depth into processes and complexities (Marshall and Rossman 2006, 53). The methodological aim of CGT is investigative; it results in empirical generalisations, explanatory theoretical frameworks and abstract, conceptual understanding of phenomena rather than universal predictions (Charmaz 2006; Luca n.d.). Most completed works, therefore, represent substantive (rather than formal) theory because they are connected to delimited problems in specific areas (Bryant and Charmaz 2010). The (substantive) theoretical framework is the 'tool that will achieve...[the advance from] everyday knowledge to a scholarly level' (Seldén 2005, 127).

Some might argue against such an eclectic research approach, but 'the challenge of research is to identify the domains of applicability of ideas rather than to discriminate between truth and falsehood as universal qualities of propositions' (Bourner and Simpson 2005, 137 original emphasis). Action learning is located within a domain of knowledge where we 'attempt to bring about some change in the world and it involves learning whatever we need to learn to bring about that change' (Bourner and Simpson 2005, 141). A substantive CGT framework enables objectification; in turn this enables

\footnotetext{
${ }^{3}$ the sociological perspective that agents' actions are related to the meanings things have for them
} 
researchers to (re)present the 'particular' (the 'whatever we need to learn'), such that it can then 'enter the experience of others and so become common property' (Blumer 1969, 158). I argue that, conflated, CGT and AL is more than the sum of its parts and, in contrast to grounded action research the powerful improvement is reciprocal.

\section{Constructivist grounded theory and critical reflection action learning in practice - a glimpse.}

Mirroring Edmonstone's (2011) approach of a glimpse into practice, and adopting Wilson's $(2010,294)$ notion of 'from practise to practice', the account below summarises my own 'experienced problem' (Coghlan and Pedler 2006, 129), explored in full within a doctoral thesis. In accordance with Coghlan and Pedler's (2006, 136-7) criteria for evaluating the quality of action learning dissertations, my thesis presented evidence of: a real problem being addressed, action being taken, and learning taking place.

\section{A real problem being addressed}

My experienced problem was an unhelpful polarity between knowledge and skills within the dominant discourse of English Post-Compulsory Education and Training (PCET, also referred to as Further Education or FE). Such polarisation risks the 'separation and superiority of mental knowledge over manual skills' (Ainley 2000, 6) and fosters an academic:vocational divide.

In order to make sense of my 'particular' experienced problem, as a teacher trainer, I wanted to learn about training PCET practitioners' underlying epistemologies; in context. As a practitioner-researcher, I also needed a reflexive research methodology which would (re)present that 'particular' such that it could then 'enter the 
experience of others and so become common property' (Blumer 1969, 158). I chose to combine a constructivist grounded theory methodology and a data-generation approach supported by the principles of action learning.

\section{Action being taken}

I developed an alternative conceptual model of knowing, dependent on a complementary relationship between knowledge and skills. Two research questions underpinned the research, one focussed on how training PCET practitioners engaged with the model; the other on what this could tell about the potential for the model to contribute to the wider conceptualisation and development of the PCET curriculum.

It was not possible to adopt a conventional approach to action learning sets, where membership remains largely constant and small groups meet regularly over a period of six to twelve months. Instead, I had the opportunity to work with fifty training practitioners spread across three undergraduate teacher training cohorts. I chose reflective workshops informed by action learning, and used these as a data-generation strategy for my research. In each of the (seven) workshops I used my model as a stimulus for reflecting on how training PCET practitioners think about knowing, which may be:

drawn from life experience ... [and] 'flawed' for being filtered through unexamined views, which may distort the person's understanding of their situation. (Mezirow $1981,183)$

In the first round a total of 34 practitioners (over three workshops) were invited to be 'issue-holders' - to identify a current, and real, problem or issue related to their professional practice (within their influence and not capable of easy solution). My role was as the facilitator. The structure of each workshop was predicated on an action 
learning set model: a warm-up activity designed to create a trusting and supportive environment; explicit sharing of values and ground rules; an initial activity based on action learning triads to enable participants to develop the skills of presenting, enabling and observing; a process review (what helped, what hindered?) and a formal ending process based on action planning (McGill and Brockbank 2004; McGill and Beaty 2001). My model was used (where appropriate) as an intervention tool, to help scaffold and delimit critical discourse. For the purposes of the research, the action planning activity was formalised through a summative artefact sheet based on two elements: personal action as a result of the reflective discussion and an individual summary of participants' engagement (or otherwise) with my model. The research dataset from the first round of workshops comprised both the summative artefacts and also my own descriptive fieldnotes and personal reaction to the workshop(s) (Marshall and Rossman 2006). These data were subject to initial coding in accordance with a grounded theory methodology. The early processes of fracturing, selecting and interpreting the data resulted in an initial understanding on my part that (some) participants had misinterpreted my model; notably as a result of some participants challenging the language used to delimit the model's dimensions.

The recognised route through which to explore relational activity within a grounded theory methodology is memoing (Bryant and Charmaz 2010; Morse et al. 2009; Charmaz 2006). I used memoing to help me appreciate both the engagement with, and also the challenge to, my model. This process enabled me to interpret the 'challenge' behaviours revealed within the dataset but, significantly (and arguably because of my status as a novice grounded theory researcher), memoing did not enable me to give those behaviours 'deliberate attention' - a key feature of action learning (McGill and Brockbank 2004). 
The grounded theory process of constant comparison functionally demonstrated that my initial categories did not adequately fit the data. However, as Rigg and Coghlan $(2010,73)$ identify 'airbrushing out' difficulties in the action learning process 'does no one any favours and does not accord with the intention of sharing learning with others'. And so, at this early stage, my own learning was enhanced by paying deliberate attention to the relationship(s) between my experience of interpreting the initial dataset and my coding action, through the critical colleagueship of my doctoral supervisor. On reflection, my supervisor and I became a pair set (McGill and Brockbank 2004) through which I was able to enter a world of 'productive disequilibrium through self-reflection, collegial dialogue, and on-going critique' (Males 2009, 930). This productive disequilibrium, which I formalised within my CGT memos, helped me to re-frame the problem and recognise that engagement which appeared to 'challenge' my model was in fact practitioners' instinctive model/s of knowing (their epistemologies) coming to light. Rather than misinterpretation, the behaviour I was observing was $r e$-interpretation of my model.

As my confidence as a grounded theory researcher grew and my experience of reflecting on my own [re]actions developed, I found that memoing became even more effective. Significantly, it relied less upon foregrounded collegial dialogue with my supervisor, and I became better able to 'search for fresh questions' (Pedler, Burgoyne and Brook 2005, 58) myself through the process of memoing; supplemented by collegial dialogue with my supervisor, as a mentor. This effectively demonstrates three of the characteristics of auto action learning: 'a dialogue between the problem owner and mentor', an approach which 'support[s] lone workers [a researcher] in a process of systematic action and learning in challenging situations', and it 'allows for reflection 
over a period of months and provides a way of encouraging 'lone workers' to follow an action/reflection cycle' (Learmonth and Pedler 2004, 172-3).

The irreducible elements of action learning (page ?) complemented the constant comparison method which is integral to grounded theory. In turn, memoing became the action which resulted from critical reflection on the experience of being a grounded theory researcher.

This process of learning about the data enabled a key development in the grounded theory process: raising the data analysis from description (conceptual coding) to a more theoretical level (initial categories). The process of constant comparison; effected through memoing, improved through productive disequilibrium, and complemented by diagramming, resulted in four potential initial categories which provided the basis for the next round of data generation.

The choices which underpin emergent data generation approaches must be made explicit within a constructivist grounded theory; Charmaz (2006) encourages these to be signposted through 'points of departure'. The synergous and iterative methodological praxis of conflating CGT's memoing process and the productive disequilibrium of AL suggested three points of departure to be explored in the second round of data generation. The first was a hypothesis generated as a result of the critical colleagueship between myself and my supervisor, the other two were questions which I needed the support of an action learning set to answer.

In the second round, therefore, I took up opportunities to be an 'issue-holder' over three reflective workshops. Within these I shared the detail of a number of 'challenges' to my model from round one. I shared examples from the data with set members to prompt critically reflective discussion to help me better understand my experienced problem, and my model was used as intervention tool (where appropriate) 
when practitioners took up opportunities to share their own professional issues. In this second round, I had the opportunity to work with 25 practitioners (five of whom had not participated in the first round), over three workshops. Set members were again asked to complete a summative artefact based on action planning, and these became part of the dataset alongside my own fieldnotes and memos.

Early theorisation of the data relied on further critically reflective memoing in order to determine the properties, scope, conditions and consequences (Charmaz 2006, 92) of my initial categories. A research approach committed to the principles of AL enabled me to explore assumptions and develop three formal categories; the CGT principle of diagramming enabled me to express the relationships between these categories. Integrative diagrams supplement theoretical memos in grounded theory; they enable a more systematic consideration of relationship(s) between categories than memo-writing alone (Strauss 1987). In turn, these diagrams supported the auto action learning process and could be shared readily with my supervisor, as mentor.

Since the categories both adequately withstood abstraction from their original context, and collectively accounted for all of the appropriate data segments, they were capable of contributing effectively to the theorisation of practitioners' engagement with my model. The iterative processes implicit to CGT had enabled me to progress securely to the stage of theoretical sampling or 'testing [my theorisation] for fit'. Significantly, the praxeological approach of combining CGT and critically reflective action learning, particularly as a novice grounded theory researcher, had effectively ensured that I avoided constructing a naïve and concrete grounded theory (Backman and Kyngäs 1999, 151).

Theoretical sampling was effected through a third data set. As before, the third reflective workshop was informed by the principles of action learning; designed to 
provide a data-generation opportunity geared towards testing my revised theoretical synthesis for fit. Seventeen practitioners participated in the final workshop. I took up the opportunity to act as an issue-holder, with an objective to explore and better understand the potential of my model in a real context, and to facilitate critically reflective discussion with others about their own professional practice. A summative artefact process was again used to gather data, with set members asked to provide an example of how they would apply my conceptual model to their own practice.

The construction of abstract understandings, or theorising as practice (Charmaz 2006) requires the CGT researcher to disregard the literal, 'plumb the depth [of the data]...while expanding the reach' and to grapple with the overt and covert to get theoretical 'level and density' (Charmaz 2006, 123-4). Critical reflection opened up the data for me, but I found I needed to read more widely on the nature of (others') understanding. Nickerson's (1995) work on representation supported this, and led me to distinguish between 'naïve' and 'dynamic' representation of understanding. In turn, over time, and through the synergies that conflating critically reflective action learning and constructivist grounded theory offer, I was able to theorise practitioners' engagement with my model in terms of them symbolising and envisaging knowing.

\section{Learning taking place}

Coghlan and Pedler (2006) recommend three lenses through which to consider the learning that has taken place in action learning scholarship: organisational-, practitionerand personal-learning. Although largely outside of the scope of this paper, organisational-learning relates to 'the wider system in which the researcher and experienced problem are located' (Coghlan and Pedler 2006, 137). My research revealed the messy reality of the post-compulsory curriculum. It revealed practitioners' normalised binary conceptualisation of knowing; echoing Malcolm and Zukas' (2001, 
33) argument that 'teaching and learning are identified as promoting...pedagogy as an educational 'transaction' between individual learners and teachers'.

The practitioners, i.e. the others who can learn immediately from this research are both 'insider' interpretive researchers (Sikes and Potts 2008) and PCET practitioners. Wider dissemination of this research, through articles such as this, further offers an opportunity for AL practitioners to learn from the research. An action-oriented approach to practice-focussed research enables a four-point strategy: i) a contextualised focus on an experienced problem, ii) the use of questioning insight as a vehicle for learning, iii) collaboration and iv) emergent learning outcomes (Fox 2009; Simpson and Bourner 2007; Pedlar, Burgoyne and Brook 2005; Rigg and Trehan, 2004) . Grounded theory is a (re)presentation method geared towards objectification of the particular. A substantive constructivist grounded theory framework enables an experienced problem ('the particular') to 'enter the experience of others and so become common property' as an explanatory framework (Blumer 1969, 158). This research has evidenced a CGT methodology supported by the principles of AL as 'proper legitimate research' (Sikes and Potts 2008, 179).

The additional advantage of an action-oriented, non-positivist research approach is the opportunity to include paradox, the divergent, and 'problem(s) facing the group' (Delamont 2002, 133) as the subject of critical exploration. This eclectic theory/practice research methodology successfully integrated evidence-based practice and practicebased evidence (Bourner and Simpson 2005), and promoted:

'...learning-from-discussions-about-the-action' and then ....re-engaging with the action in light of that learning; a kind of 'learning-from-talking-about-action-andacting-from-that-learning'. (Fox 2009, 7) 
Finally, personal learning can be effectively captured in Wilson's (2010 294) notion of 'from practise to practice' - the reflexive accounting that is commonplace in accounts of action-oriented research. Similarly, in CGT, Charmaz $(2006,181)$ identifies that 'the sense we make of the journey takes place from our completed work'. For me, the constructivist grounded theory framework I developed helped me understand the reality of my experienced problem. In terms of the 'journey' the methodological praxis of CGT supported by the principles of AL was ambitious, but advantageous to the novice doctoral-level researcher. Critical reflection action learning and constructivist grounded theory are not interchangeable, however, the shared characteristics (Table 1) comprise an almost genetic relationship in practice. I have developed a critical understanding of this relationship; one which was not evident to me in the established literature when my research journey began.

\section{Implications for practice}

In their 2005 paper, Pedler, Burgoyne and Brook explore what action learning has learned to become. They consider action learning both as a method and also as an ethos. Within this they reflect upon the notion of Revans' 'classical principles', the last of which in their list is:

the search for fresh questions and 'q' (questioning insight) takes primacy over access to expert knowledge or 'p' (Pedler, Burgoyne and Brook 2005, 59).

Critical reflection action learning, as an ethos, enabled me as a novice in grounded theory to start thinking as a grounded theorist in an environment where there was limited access to expert knowledge [and in fact where I was building a new contribution to knowledge]. Simultaneously, the processes implicit within CGT (fracturing, selecting, relating and integrating data) were the actions from which my 
learning developed; they presented and generated problems to which there were no right answers, and they were the basis of 'profound personal development resulting from reflection upon action' (Pedler, Burgoyne and Brook 2005, 58). In common with Baskerville and Pries-Heje's (1999) work on grounded action research, my experience was that critically reflective action learning powerfully improved the constructivist grounded theory methodology. In contrast to their work, I found that the constructivist grounded theory methodology also powerfully improved my critically reflective action learning experience. The relationship was reciprocal.

Two distinct implications for practice can be drawn from this experience. Firstly, there is sufficient 'grab and fit' in conflating these two, traditionally unrelated, concepts. Revans argued that action learning is the bridge between the world of action and the world of learning (1983 cited in McGill and Beaty 2001); I argue that constructivist grounded theory enables the nature of that bridge to be explored. The (substantive) explanatory theoretical frameworks constructed through this secondgeneration GT approach are the 'tool[s] that will achieve... [the advance from] everyday knowledge to a scholarly level' (Seldén 2005, 127) which can then 'enter the experience of others and so become common property' (Blumer 1969, 158).

Secondly, as a new praxis, this 'theory/practice' methodology offers significant advantages to postgraduate researchers. Pair sets and auto action learning, enacted through the relationship between researcher and supervisor, offer opportunities for framing and re-framing which can powerfully improve the researcher's opportunity, as a 'lone worker', to follow an action/reflection cycle (Learmonth and Pedler 2004). In turn, the CGT practice of identifying points of departure (Charmaz 2006) can be powerfully improved through the conflation of memoing, diagramming and the productive disequilibrium of AL; increasing the likelihood that a 'lone worker' 
researcher will avoid constructing a 'naïve and concrete' (Backman and Kyngäs 1999, 151) explanation of an experienced problem.

Earlier in 2013, David Coghlan reported on the discussion which focussed on action learning research at the Third International Conference on Action Learning. In considering the sceptical position, he asks:

...while action learning research involves turning $\mathrm{Q}$ into $\mathrm{P}$, are there limitations from an individual case and setting in which the action learning takes place that inhibit it being called research? What kind of theory is generated by action learning research? (Coghlan 2013, 56)

Substantive, explanatory theoretical frameworks borne of constructivist grounded theory underpinned by the principles of critical reflection action learning may provide an answer.

\section{Notes on contributor}

Jane Rand is a Senior Lecturer in Education Studies at York St John University. After completing an EdD at the University of Sheffield in 2012, Jane joined York St John from the Further Education Sector where she worked as a teacher trainer. Her core interests are epistemologies, qualitative research methodologies and applied pedagogical research.

\section{References}

Ainley, P. 2000. Teaching in a Learning Society, the Acquisition of Professional Skills. Paper presented at the ESRC Teaching and Learning First Programme 
Conference, November, at the University of Leicester, England.

http://www.tlrp.org/acadpub/Ainley2000.pdf

Backman, K., and H. Kyngäs. 1999. Challenges of the grounded theory approach to a novice researcher. Nursing and Health Sciences 1: 147-53.

Baskerville, R, and J. Pries-Heje. 1999. Grounded action research: a method for understanding IT in practice. Accounting Management and Information Technologies 9: 1-23.

Blumer, H. 1969. Symbolic Interactionism. Perspective and Method. Berkeley, CA: University of California Press.

Bourner, T., and P. Simpson. 2005. Practitioner-centred research and the Ph.D. Action Learning: Research and Practice 2, no.2: 133-51.

Bryant, A., and K. Charmaz., eds. 2010. The SAGE Handbook of Grounded Theory. Paperback ed. London, England: Sage.

Charmaz, K. 2006. Constructing Grounded Theory A Practical Guide Through Qualitative Analysis. London, England: Sage.

Charmaz, K. 2009. Shifting the Grounds: Constructivist Grounded Theory Methods. In Developing Grounded Theory The Second Generation, ed. J. Morse, 127-93. Walnut Creek, CA: Left Coast Press.

Coghlan, D. 2013. Action learning research? Reflections from the colloquium at the Third International Conference on Action Learning. Action Learning Research and Practice 10, no. 1: 54-57.

Coghlan, D., and M. Pedler. 2006. Action learning dissertations: structure, supervision and examination. Action Learning Research and Practice 3, no. 2: 127-39.

Delamont, S. 2002. Fieldwork in Educational Settings: methods, pitfalls and perspectives. 2nd ed.. London, England: Routledge.

Edmonstone, J. 2011. Action learning and organisation development: overlapping fields of practice. Action Learning Research and Practice 8, no. 2: 93-102.

Fox, S. 2009. Following the action in action learning: towards ethnomethodological studies of (critical) action learning. Action Learning: Research and Practice 6, no. 1: 5-16.

Kember, D. 2000. Action Learning and Action Research. Improving the quality of teaching and learning. London, England: Kogan Page. 
Learmonth, A., and M. Pedler. 2004. Auto Action Learning: a tool for policy change. Building capacity across the developing regional system to improve health in the North East of England. Health Policy 68: 169-181.

Locke, K. 2001. Grounded Theory in Management Research. London, England: Sage.

Lord, B. 1994 Teachers' professional development: Critical colleagueship and the role of professional communities. In The Future of Education: Perspectives on national standards in education, ed. N.Cobb, 175-204. New York: College Board.

Luca, M. n.d. Embodied Research and Grounded Theory. http://www.wales.ac.uk/en/featuredcontent/ articles/staffarticles/EmbodiedResearchandGroundedTheory.aspx

Malcolm, J., and M. Zukas. 2001. Bridging Pedagogic Gaps: Conceptual discontinuities in higher education. Teaching in Higher Education. 6, no. 1: 33-42.

Males, Lorraine. 2009. Confronting practice: Critical colleagueship in a mathematics teacher study group. Paper presented at the annual conference of the North American Chapter of the International Group for the Psychology of Mathematics Education, Atlanta, GA. http://michiganstate.academia.edu/LorraineMales/Papers/412689/Confronting_P ractice_Critical_Colleagueship_In_a_Mathematics_Teacher_Study_Group

Marshall, C., and G.B. Rossman. 2006. Designing Qualitative Research. 4th ed. London, England: Sage.

McGill, I. and L. Beaty. 2001. Action Learning - a guide for professional, management and educational development. Rev. 2nd ed. Abingdon, England: RoutledgeFalmer.

McGill, I. and A Brockbank. 2004. The Action Learning handbook. Abingdon, England:RoutledgeFalmer.

Mezirow, J. 1981. A critical theory of adult learning and education. Adult Education 32, no. 1: 3-24.

Morse, J., ed. 2009a. Developing Grounded Theory The Second Generation. Walnut Creek, CA: Left Coast Press.

Morse, J. 2009b Tussles, Tensions, and Resolutions. In . Developing Grounded Theory The Second Generation, ed. J. Morse, 13-23. Walnut Creek, CA: Left Coast Press. 
Morse, J., A. Clarke, B. Bowers, K. Charmaz, J. Corbin, and P. Stern. 2009 Grounded Theories: on Solid Ground. In Developing Grounded Theory The Second Generation, ed. J. Morse, 236-250. Walnut Creek, CA: Left Coast Press.

Nickerson, R.S. 1985. Understanding Understanding. American Journal of Education 93, no. 2: 201-239.

Pedler, M., J. Burgoyne, and C. Brook. 2005. What has action learning learned to become? Action Learning: Research and Practice 2, no. 1: 49-68.

Plauborg, H. 2009. Opportunities and limitations for learning within teachers' collaboration in teams: perspectives from action learning. Action Learning: Research and Practice 6, no. 1: 25-34.

Rand, J. 2011. Dimensions of knowing: a constructivist exploration of a conceptual model in a real context. EdD diss., University of Sheffield.

Rigg, C., and D. Coghlan. 2010. Introduction to accounts of practice. Facing the challenges within. Action Learning: Research and Practice 7, no. 1: 73.

Rigg, C., and K. Trehan. 2004. Reflections on working with critical action learning. Action Learning: Research and Practice 1, no. 2: 149-63.

Seldén, L. 2005. On Grounded Theory - with some malice. Journal of Documentation 61, no. 1: 114-129.

Shannak, R., and F. Aldhmour. 2009. Grounded Theory as a Methodology for Theory Generation in Information Systems Research. European Journal of Economics, Finance and Administrative Sciences, 15: 32-50.

Sikes, P., and A. Potts, eds. 2008. Researching Education from the Inside. Investigations from within. Abingdon, England: Routledge.

Simpson, P., and T. Bourner. 2007. What action learning is not in the twenty-first century. Action Learning: Research and Practice 4, no. 2: 173-87.

Stern, P. 2009. In the Beginning Glaser and Strauss created Grounded Theory. In Developing Grounded Theory The Second Generation, ed. J. Morse, 24-34. Walnut Creek, CA: Left Coast Press.

Strauss, A. 1987. Qualitative Analysis for Social Scientists. Cambridge, England: Cambridge University Press.

Strauss, A., and J. Corbin. 1998. Basics of Qualitative Research. Techniques and Procedures for Developing Grounded Theory. London, England: Sage. 
Thomas, G., and D. James. 2006. Reinventing grounded theory: some questions about theory, ground and discovery. British Educational Research Journal 32, no. 6: 767-95.

Walker, D., and F. Myrick. 2006. Grounded Theory: An Exploration of Process and Procedure. Qualitative Health Research 16, no.4: 547-559.

Wilson, O. 2010. Account of Practice. From practise to practice: action learning to support Transforming Derby. Action Learning: Research and Practice 7, no. 3: 287-95. 